\title{
ADANA OVASININ ISLAHI PROJESİ (1924)
}

\author{
Y1ldiray YILDIRIM ${ }^{1}$
}

\begin{tabular}{|c|c|}
\hline \multicolumn{2}{|c|}{ Makale Bilgisi } \\
\hline \multirow{2}{*}{\multicolumn{2}{|c|}{$\begin{array}{l}\text { Kavramsal Makale } \\
\text { DOI: } 10.35379 / \text { cusosbil.1035601 }\end{array}$}} \\
\hline & \\
\hline \multicolumn{2}{|c|}{ Makale Geçmişi: } \\
\hline Geliş & 12.12 .2021 \\
\hline Düzeltme & 27.12.2021 \\
\hline Kabul & 28.12 .2021 \\
\hline \multicolumn{2}{|c|}{ Anahtar Kelimeler: } \\
\hline \multicolumn{2}{|c|}{ Adana Ovasi, } \\
\hline \multicolumn{2}{|l|}{ Tarım, } \\
\hline \multicolumn{2}{|c|}{ Süleyman Sırrı Bey, } \\
\hline 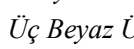 & Tretimi. \\
\hline
\end{tabular}

\section{IMPROVEMENT PROJECT OF ADANA PLAIN (1924)}

\begin{abstract}
ÖZ
Türkiye Cumhuriyeti'nin ilk Nafia Bakanı Süleyman Sırrı Bey (Aral), 1924 yılında Adana Ovası'nın ıslahı için bir proje hazırlamıştır. Projede, İzmir İktisat Kongresi'nde alınan kararlar doğrultusunda Adana Ovası'nda, üç beyaz olarak adlandırılan buğday, pamuk ve şeker üretilmesi hedeflenmiştir. Bu sayede ülke ekonomisine önemli katkı sağlanacağı ve döviz çıktısının azaltılacağı düşünülmüştür. Projede, bölgenin coğrafi konumu, iklimi, bataklıklar, ulaşım ve sulama gibi konulara yer verilmiştir. Ancak çalışmanın esasını bölgenin sulanması ile bu üç ürünün ekilmesi durumunda ülkenin elde edeceği kazançlar oluşturmaktadır. Hazırlanan projede tespit edilen tüm sorunlar ve tarım üretimini arttırma düşüncesi Osmanlı Devleti'nin son döneminde de ele alınan konulardır. Fakat bu girişimler ülkenin içinde bulunduğu olumsuz şartlar nedeniyle yeteri kadar gerçekleşememiştir. Sırrı Bey'in projesi de benzer nedenlerle hayata geçirilememiştir. Bu yüzden Adana Ovası'ndan verimli bir şekilde yararlanmak ancak 1956'da inşa edilen barajdan sonra mümkün olabilmiştir. Bu çalışma, Süleyman Sırrı Bey'in Adana Ovası hakkında işaret ettiği sorunların Osmanlı Devleti'nin son dönemindeki durumu ile karşılaştırılarak bütüncül bir yaklaşımla ele alınmasını hedeflemektedir.
\end{abstract}

\begin{tabular}{l} 
Article Info \\
\hline Conceptual Article \\
DOI: $10.35379 /$ cusosbil.1035601 \\
\hline Article History: \\
Received $\quad 12.12 .2021$ \\
Revised $\quad 27.12 .2021$ \\
Accepted $\quad 28.12 .2021$ \\
\hline Keywords: \\
Adana Plain, \\
Agriculture, \\
Mister Süleyman Sirr, \\
Three Whites Production.
\end{tabular}

${ }^{1}$ Dr. Bayburt Üniversitesi, İnsan ve Toplum Bilimleri Fakültesi, Tarih Bölümü, yyildirim@bayburt.edu.tr, ORCID 0000-0002-7175-370X Alıntılamak için/ Cite as: Yıldırım, Y. (2021), Adana Ovasının Islahı Projesi (1924), Çukurova Üniversitesi Sosyal Bilimler Enstitüsü Dergisi, 30 (3), 206-222. 
Çukurova Üniversitesi Sosyal Bilimler Enstitüsü Dergisi, Cilt 30, Sayı 3, 2021, Sayfa 206-222

\section{GiRis}

Osmanlı Devleti, 1914 yılında katıldığı I. Dünya Savaşı'ndan, 30 Ekim 1918 tarihinde imzaladığı Mondros Ateşkes Antlaşması ile yenik olarak ayrılmıştı. Antlaşmanın ardından başlayan işgallere karşı Anadolu'da Millî Mücadele hareketi başladı ve bu mücadeleden Türkiye zaferle çıktı. Zaferin ardından I. Dünya Savaşı'nın galip devletleri ile Türkiye arasında 20 Kasım 1922 tarihinde Lozan'da barış görüşmeleri başladı. Görüşmeler sırasında en çetin geçen konulardan biri kapitülasyonlar ile Türkiye'nin ekonomik ve mali bağımsızlık meselesiydi. Görüşmelere, iki taraf arasında yaşanan görüş ayrılıkları nedeniyle 4 Şubat 1923 tarihinde ara verildi. Kısa bir süre sonra 17 Şubat 1923 tarihinde Lozan'da ülkeyi çok uğraştıran iktisadi sorunlara çare bulmak ve ülkeyi yeniden ayağa kaldırmak amacıyla İzmir İktisat Kongresi toplandı (İnan, 1989, s.10-12).

Kongrenin açılış konuşmasında Atatürk, ülkenin tam bağımsızlı̆̆ açıklamaktaydı:"Tam bağımsızlık için şu ilke vardır: Milli egemenlik, ekonomik egemenlikle sağlamlaştırllmalıdır... Siyasi ve askeri zaferler, ne kadar büyük olursa olsun, ekonomik zaferlerle taçlandırllmazlarsa kazanılacak başarılar yaşayamaz, az zamanda söner.” Bu ifade işgalci devletlere karşı kazanılan zaferin ardından emperyalizme karşı yapılacak mücadelenin parolasıydı (Haktan, 1998, s. 31; Ökçün, 1981, s. 251; Atatürk'ün Söylev ve Demeçleri, 1997, s.111). Kongrede alınan kararlar Türkiye Cumhuriyeti'nin ülkede uygulayacağ 1 iktisadi düşüncenin temelini oluşturdu ve sonraki yedi yıl boyunca iktisadi politikalar bu çerçevede yürütüldü. Fakat Kongre'de sanayi alanında kalkınmak için kararlar alınmış olsa da Osmanlı ekonomisinin ana kolu tarıma dayanmaktaydı. Hâlâ nüfusunun büyük çoğunluğu kırsalda yaşamakla birlikte tarım ve hayvancılıkla uğraşıyordu. Bu nedenle ekonomik kalkınma, en hızlı şekilde tarım üzerinden mümkün olabilirdi (Öksüz, 2016, s. 213-218). Tarım içerisinde de daha sonraları "üç beyaz" olarak adlandırılacak şeker, buğday ve pamuk üretimi öncelikliydi. Bu kalemlerin yerli üretimle karşılanarak döviz çıktısının azaltılması hedeflenmişti (Doğan, 2009, s. 238). Tarımın hâlâ modern tekniklerle yapılmayışı, makineleşmenin sağlanamayışı yanında sel ve sulama gibi sorunlar nedeniyle tarım arazilerinden yeteri derecede istifade edilemiyordu. $\mathrm{Bu}$ nedenlerle Cumhuriyetin ilk yıllarında yönetici kadro tarafından ülke ekonomisini kalkındırmak amacıyla tarımsal kalkınmaya ağırlık verildi ve bunun için bazı projeler hazırlandı. Bu kişilerden biri de 19 Ocak 1924 - 22 Kasım 1924 ve 03 Mart 1925 - 16 Aralık 1925 tarihlerinde iki kez Bayındırlık Bakanlığı (Nafia Vekilliği) yapan Süleyman Sırrı (ARAL) Bey'di (Tulga \& Parlayan, 2009, s. 24-25;). ${ }^{2}$ Sirrı Bey, 22 Mart 1924 tarihinde yapılan meclis toplantısındaki tartışmalarda özellikle nehirlerden faydalanılması ve ovaların 1slahı üzerinde durmuştu. O, bu konuda daha önce ovaların sulanması konusunda Konya Ovası'nda (Büyükyıldırım, 2009, s. 36-39) çalışmaların yapılmış olduğunu vurguladıktan sonra Bursa-Kirmastı Ovası'nın keşif çalışmalarının bittiğini, Adana ile Menderes ovalarının keşif çalışmalarına başlandığını ifade etmiş ve çalışma yapılan yerler hakkında bilgiler vermiştir (Türkiye Büyük Millet Meclisi Zabıt Ceridesi, 1924, s. 895, 949). Aynı yıl Adana Ovası'nın keşif çalışması tamamlandı ve bu rapor bir kitapçık olarak basıldı. Raporda, İktisat Kongresi sonucunda ortaya çıkan üç beyazın üretimi temel alınmış bu üretimin ülkeye ve bölgeye getireceği avantajlar ile ülkenin bu üretimden sağlayacağı maddi kazanç ön planda tutulmuştur.

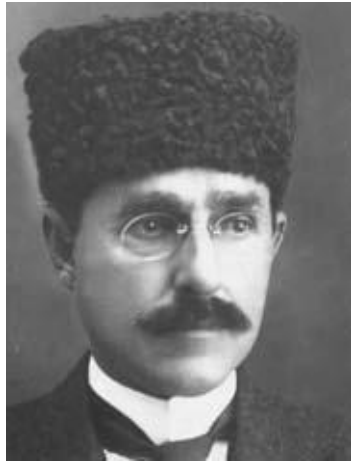
Adana Ovası'nın sulanması için yapılması gerekenlerin dışında bölgenin coğrafyası, ulaşımı ve tarım üretimi konularındaki sorunlar hakkında bilgilere yer verilmiştir. Bu çalışma, Sırrı Bey’in hazırladığı rapor temelinde Adana Ovası'nın Cumhuriyet'in ilk yıllarındaki genel durumunun, üretim potansiyelinin, üretimi engelleyen temel nedenlerin ve bu konuda yapılacak çalışmaların gerçekleşmesi halinde ülkenin elde edeceği faydaların neler olabileceğini tespit etmeyi amaçlamaktadır. Ayrıca çalışmada yer alan konular, Osmanlı'nın son dönemiyle karşılaştırılarak bütüncül bir yaklaşımla ele alınmıştır. Bu karşılaştırma, hazırlanan projeden sağlanacak faydayı daha açık bir şekilde ortaya koymaktadır.

\footnotetext{
${ }^{2}$ Mustafa Kemal Atatürk'ün ikinci dereceden akrabası olan, Süleyman Sırrı Bey, 1874 yılında Selanik’te doğmuştur. Mühendis mektebinden mezun olmuș ve Suriye Bayındırlık Bașmühendis Yardımcılı̆̆ı, Yanya Merkez Mühendisliği ve İdadi Öğretmenliği, Bağdat Hendesiye Seddi Mühendisliği, Kudüs, Bursa Bayındırlık Başmühendisliği, Bayındırlık Bakanlığı Turuk u Maabir Müdür Muavinliği, Nâfıa Vekâleti Nâfia Umûm Müdürlüğ̈̈, Mühendislik Okulu Öğretmenliği yapmıştır. Cumhuriyet'in ilk yıllarında II. Dönem İstanbul Milletvekilliği ile 1., 2. ve 4. Hükümet Nâfı Vekili görevlerini ifa etmiştir. Görevi başındayken 15.12.1925 tarihinde hayatını kaybetmiştir. TBMM Albümü 1920-2010, (Cilt.1), Ankara: TBMM Basın ve Halkla Iliskiler Müdürlügü Yayınları, 2010, s. 101; Nafia Nezareti'nden Çevre ve Şehircilik Bakanlı̆̆ına Görev Yapmış Bakanlarımız(1848-...), https://webdosya.csb.gov.tr/db/turkce/ eskibakanlar/ dergi/mobile/index.html.
} 


\section{ADANA OVASI'NIN GENEL DURUMU}

Adana Ovası'nın (Ceyhan ile Berdan Çayı arası) güneyi, güneydoğusu ve güneybatısı Akdeniz'le; kuzeydoğusu, kuzeybatısı ve kuzeyi ise dağlarla çevrili olduğundan iklimi, orta kuşağın (Yengeç DönencesiKuzey Kutup Dairesi) en sıcak kısımlarına yaklaşmaktadır. Bölgenin senelik ortalama sıcaklığı 21 derece iken kış mevsiminin ortalaması 15 derecedir (Süleyman Sırrı, R. 1340, s. 3). Meteoroloji Genel Müdürlüğünün 19292018 yılları arasını kapsayan ölçümlerinde ise Adana'nın ortalama sıcaklığı; kış mevsiminde 9.5, yaz mevsiminde 28.8 olmak üzere genel ortalama 19.1 derece olarak tespit edilmiştir (Meteoroloji Genel Müdürlüğü, 2021). Adana Ovası'ndaki sıcaklık, Mısır ve Irak ile karşılaştırıldığında bu bölgelerde sıcaklığın fazla yükselmesine karşın Adana Ovası'nda o kadar yükselmemektedir. Mevsimlerdeki sıcaklık farkı, bu bölgelere kıyasla fazla olmayıp daha düzenli hareket etmektedir. Gün içindeki sıcaklık değişimi ile gece-gündüz arasındaki fark da daha azdır. Doğal olarak karşılaştırılan bölgeler karasal ve çöl iklimine sahip olmasına karşın Adana bölgesinin hem denize yakınlığı hem de nem oranının yüksekliği buna neden olmaktadır. Don olayı ve kar yağışı nadiren gerçekleşmekle beraber kar yer üstünde tutmamaktadır. Yağmuru ise az olup ekinlerin suya ihtiyaç duyduğu dönemlerde yağmıyordur. Adana Ovası'na her yıl düşen yağmur miktarı çok büyük farklılık göstermektedir. Ortalama 0,615 metreküp civarında olan yağış miktarı bazı yıllarda bunun ancak yarısı kadar gerçekleşmektedir. Bu miktar, ekinler için yetersiz olsa dahi bir dereceye kadar su ihtiyacını azaltabileceği düşünülebilir. Fakat ekinlerin suya ihtiyaç duyduğu İlkbahar ile Yaz mevsimlerinde yağan yağmur toplam yağmur miktarının ancak üçte biri oranındadır ve bu da ekinler için yeterli değildir. Bundan dolayı ziraattan elde edilen verim oldukça sınırlı ve yetersiz kalmaktadır (Süleyman Sırı, R. 1340, s. 3). Günümüzdeki verilerin de ortaya koyduğu gibi bölgede Ekim ayında başlayıp Aralık ayında zirveye ulaşan yoğun yağışlarda Mayıs ayı ile birlikte ciddi bir düşüş yaşanmaktadır. Haziran-Eylül aylarını kapsayan dönemde ortalama yağışlı gün sayısı ancak 7,1'dir (Meteoroloji Genel Müdürlüğü, 2021).

Yaz ve Sonbahar mevsimlerinde deniz tarafından genellikle güney rüzgârları (Lodos-Kıble-Kesişleme) orta derecede esmektedir. Kış mevsiminde sert esen Kuzey rüzgârları (Karayel-Yıldız-Poyraz), yazın güneşin sıcaklığını alan dağlar yönünden estiğinden bu rüzgârlar sıcak olur. Sonbaharda ekinlere zarar verebilecek rüzgârlar ise nadiren esmektedir. Adana Ovası'nda Berdan Çayı, Seyhan ve Ceyhan ırmakları olmak üzere sulamada faydalanılabilecek üç su kaynağı mevcuttur. Bunlar, Toros Dağları ile bağlantılarından çıkarak, aniden eğimi 0,000433 olan ovaya akmaktadır. Bazen getirdikleri su miktarının çok fazla olmasından dolayı akan su nehir yataklarına sığmayarak etrafa yayılıp ekinlere zarar vermektedir. Ayrıca taşma sonucunda kıymetli araziler sular altında kaldığından buralardan faydalanılamamaktadır. Taşma sonrasında ortaya çıkan bataklıklar pek çok zarara neden olmakta, hatta can kayıpları dahi yaşanmaktadır (Süleyman Sırrı, R. 1340, s. 3).

\section{PROJEYE GÖRE YAPILMASI PLANLANAN FAALIYETLER}

Sırrı Bey, Adana Ovası'nda yapılması planlanan faaliyetleri beş madde olarak sıralamıştır. Bunlardan ilk ikisi sel sularının vermekte olduğu zararların ve bataklıkların önlenmesidir. Ancak tespit edilen bu iki meselenin çözümüne dair herhangi bir açıklamaya veya nasıl bir çalışma yapılacağına dair bir bilgiye yer verilmemiştir. Yukarıda da ifade edildiği üzere Toroslardan aniden düzlüğe inen su, bahar mevsiminde karların erimesi ve bahar yağmurları nedeniyle taşmalara neden olmaktadır. Nehirlerden taşan sular yazın havaların 1sınması ve yağışların azalmasıyla çekilince geride ciddi bataklıklar oluşmaktadır. Bu durum, özellikle sivrisineklerin artması yüzünden sitma hastalığına sebebiyet vermekte ve tarımı da olumsuz etkilemektedir (Çatal, 2015, s. 293). Aslında Osmanlı Devleti'nin yaklaşık son elli yılında bölgedeki bu sorunlara dair bazı çalışmalar yapılmıştı. Adana-Tarsus arasındaki bataklıklar 1870'lerde büyük oranda kurutulmuştu (Toksöz, 2006, s. 101). Bataklıkların kurutulması için doldurma yöntemi yanında ağaçlandırma yapılması da düşünülmüştü. $\mathrm{Bu}$ ağaçlardan biri halk arasında "Sıtma Ağacı" olarak da bilinen okaliptüs ağacıydı (Türker, 2008, s. 251; Özgün, 2013, s.6). ${ }^{3}$ Günümüzde bölgede yoğun olarak görülen bu ağacın o tarihlerde tohumunun yurt dışından getirilmesi ve maliyetinin yüksek olması nedenleriyle yaygınlık kazanmadığı tahmin edilmektedir. Halk bunun yerine daha kolay erişebildikleri çam, kavak, söğüt ve dişbudak gibi ağaçları dikmeyi tercih etmiştir (Özgün, 2013, s. 13-14). Seyhan-Ceyhan arasındaki ovalık bölge de yine taşmalar neticesinde çoğu zaman bir çamur deryası halini almakta ve oluşan bataklıklar ziraatı engellediği gibi sttmaya neden olmaktadır (BOA, DH.ID.,

\footnotetext{
${ }^{3}$ Okaliptüs ağacı, bünyesinde yaklaşık 250-300 kilo kadar su barındırmakta ve her yıl 250 ton kadar suyu havaya aktarmaktadır. Osmanlı döneminde ilk kez 1880 yılının başlarında dikilmeye başlanan okaliptüs ağacı bataklıkların kurutulması için de düşünülmüştü. Tarsus Karabucak bataklığının kurutulması amacıyla 1883 yılında bir İngiliz şirkete ihale edilen bu işs, şirketin bu işin altından kalkamayacağı düşüncesi neticesinde gerçekleşmedi. Burası ancak 1939 yılında ekilen okaliptüs ağaçlarıyla kurutulmuştur.
} 
80/26-3.) Bataklıkların oluşmasını engellemek için en etkili çözüm baraj kurmak ya da nehirlerin taşmasını önleyecek setler yapmaktır. Osmanlı Devleti bunun için de çalışmalar yürütmüştü. Ancak yapılan setler daha ziyade şehir merkezinde gerçekleşmiştir. Bölgedeki taşmaların tamamen önlenmesi için nehrin Toroslardan denize kadar olan iki yanına set çekmek gerekmektedir. Bu, o dönemlerde hem çok büyük bir insan gücü hem de para gerektirmekte, devletin de buna yetecek ekonomik gücü bulunmamaktadır. Bu nedenle 1910 y1lında bataklıkların kurutulmasından ziyade bölgenin sulanması amacıyla ancak gereken yerlere setler yapılması için keşif çalışmalarının yürütülmesine, haritalarının çıkarılmasına ve bu işin bir şirkete ihale edilmesine karar verilmiştir (BOA, DH.MKT., 263/13; BOA, DH.MKT., 423/30; BOA, BEO., 3705/277845).

Raporun üçüncü maddesinde, bölgede yağmurun yeterli ve düzenli yağmaması nedeniyle şeker kamışı ve pamuk gibi pek çok fayda sağlayan mahsullerin yetiştirilmesi için Adana Ovası'nda sulama faaliyetlerinin gerçekleştirilmesi gerektiği ifade edilmektedir. Bu çerçevede yapılan hesaplamalar ve gözlemlere göre Berdan Çayı ile Tarsus-Mersin demiryolu ve bu çay arasındaki arazinin sulanması mümkündür. Seyhan Irmağıyla Adana-Tarsus demiryolunun birkaç kilometre kuzeyinden başlayan ve Berdan Çayı ile Seyhan Irmağı arasında uzanan arazinin tamamen ve Seyhan ile Ceyhan arasındaki arazinin de büyük bir kısmının sulanması sağlanabilirdi. Geriye kalan kısmın da Ceyhan Irmağı'yla sulanması planlanmıştır. Ayrıca yapılan hesaplara göre Ceyhan Irmağı'nın suları buranın sulanmasına fazlasıyla yeteceğinden kalanıyla Çukurova'nın diğer kısımlarının sulanması da mümkündü (Süleyman Sırrı, R. 1340, s. 4). Yapılacak faaliyet kapsamlı olacağı için çalışmalara topyekûn değil kademeli bir şekilde başlanılması düşünülmüştür. Bu doğrultuda öncelikle ya Berdan Çayı'na ait çalışmalar veyahut Seyhan ile Seyhan-Berdan arasındaki kısmın sulanmasına başlanmalıydı. Daha sonra Berdan Çayı'na ait çalışmalara başlanması ve en sonunda da Seyhan ile Ceyhan arasındaki ovanın sulanmasının gerçekleştirilmesi planlanmıştır. Ancak önceliğin hangi çalışmalara verileceği başlatılan incelemelerin neticesinde elde edilecek faydaların göstereceği lüzuma göre şekillenecekti. Ayrıca bölgenin verimli toprakları, yetiştirilecek mahsulü, coğrafi konumu ve nakliye vasıtaları dikkate alındığında Çukurova da Adana Ovası kadar önemliydi. Bu nedenle Adana Ovası'ndaki çalışmalardan bir kısmının yapılmasının ardından Çukurova için gerekli görülecek lüzum ve yapılacak hesaplar çerçevesinde çalışmalara başlanacaktı. Bu ovanın arazi miktarı da Adana Ovası kadar verimli olduğu gibi, elde edilecek faydalar da hemen hemen aynıydı (Süleyman Sırrı, R. 1340, s. 5-6).

Diğer meseleler gibi sulama işi de Osmanlı döneminde ele alınan önemli konulardandı. Örneğin 1899 yılında Cezayir-i Bahr-i Sefid Valisi bulunan ve daha evvel Adana Valiliği yapan Abidin Paşa, Adana Ovası'nın sulanması için sermaye verecek olan bir Belçikalı girişimci adına hükümetten izin istemiş ve bu iznin verilmesi halinde hem ahalinin hem de hazinenin bundan büyük istifade edeceği belirtilmiştir (BOA, Y.PRK.UM., 46/3). Ardından 1902 yılında Çukurova'nın kanallar açılarak sulanmasını öngören bir teklif sunulmuştur. Teklifte, yukarıda bahsedilen üç büyük nehirden, ovanın sulanması amacıyla uygun yerlere kanallar açılması ve bu sayede tarım üretiminin arttırılması düşünülmüştür (Yaktı, 2013, s. 285). Daha sonra Hindistan'da bazı bataklıkların kurutulması ve sulama faaliyetlerinin gerçekleştirilmesinde büyük başarı sağlayan İngiliz mühendis Sir William Winkoff, Fırat ve Dicle bölgesinin sulanması için bir rapor ve harita hazırlamış, 1906 yılında Adana bölgesindeki sulama işleri ve bataklıkların kurutulması için de bölgede bir keşif ve tahkikat yapma talebinde bulunmuştur (BOA, Y.A.HUS., 505/42). Bu tarihlerde Adana Ovası'nın sulanması için çabaların yoğunlaştığı anlaşılmaktadır. Yapılan çalışmalar neticesinde 1908 yılında şehrin kuzeyinde 7 metre yüksekliğinde bir baraj planı hazırlanmıştır (Yurtsever, 2018, s. 82-83). Ardından 1909 yılında bölgenin yol ve sulama haritaları çıkarılmıştır (BOA, HRT.h. 2424; BOA, HRT.h. 2042). Aynı yıl Irak, Rumeli ve Adana Vilayeti'nin sulanması için Avrupa'dan mühendisler getirilmesine karar verilmiştir. Irak ve Rumeli için üç mühendis istenirken, Adana için uygun maaşla bir mühendis getirilmesi hedeflenmiştir (BOA, MV, 120/23). Fakat Osmanlı Devleti, hazırlanan rapor ve haritalardan bir netice elde edemediği gibi yapılması gereken çalışmaları uygulayacak maddi imkânlara da sahip değildi. Bu nedenle bölgenin sulanması için yapılması gereken inşaat ve işletme faaliyetlerinin imtiyaz suretiyle ve ihale yoluyla verilmesine karar verildi. İşi üstlenecek müteahhit veya şirkete ya inşaat için belli bir ücret ödenecek ya da inşaat işiyle birlikte işletme işini de üstlenenler, kazançlarından devlete belli bir pay verecekti. Ayrıca taraflar arasında yapılacak anlaşmada devlet dilediği zaman imtiyaz hakkını satın alabilecekti. Bu karar 14 Ağustos 1909 tarihinde Osmanlı ve Avrupa gazetelerinde ilan edildi (BOA, MV., 132/94). 
Cumhuriyet döneminde Sırrı Bey'in bu konuda çalışma yürüttüğü tarihlerde de Avrupa'dan mühendisler getirilmeye devam edildi. Örneğin bunlardan biri Macar mühendis Joseph Harrer ${ }^{4}$ idi. Gerek Osmanlı döneminde yapılan tüm bu girişimler gerekse Cumhuriyet'in ilk yıllarındaki teşebbüsler ülkenin ekonomik şartları, yaşanan savaşlar ve buhranlar gibi nedenlerden dolayı hayata geçirilemedi. Yapılan çalışmalar veya girişimler istenilen sonucu vermediğinden Cumhuriyet döneminde de ciddi sel felaketleri yaşanmaya devam etmiş̧tir. Buna rağmen Osmanlı'nın son döneminden başlayarak bu sorunların çözülmesi için bir altyapı oluşmuştur. Oluşan bu altyapı neticesinde sorunlar 1953 yllında inşaatına başlanan ve 1956 yllında tamamlanarak faaliyete geçen Seyhan Barajı'nın yapılmasıyla büyük oranda ortadan kalkmıştır (Çanak, 2015, s. 337). Baraj inşaatından hemen sonra hem ovanın sulanması hem de ovanın taşkından korunması amacıyla projeler hazırlanmıştır. Böylelikle oluşan bataklıkların önüne geçilmiştir. Dört aşamadan oluşan bu projenin 1. kısmı 1957-1968, 2. kısmı 1969-1974 ve 3. kısmı 1976-1985 yılları arasında tamamlanmıştır. Son aşamada ise 40.657 hektarlık alan ile birlikte TarsusCeyhan arasındaki toplam 173.638 hektarlık arazi, su kanalları ve su tekneleri sayesinde sulanması sağlanmıştır (İnşaat Mühendisleri Odası, 2006, s. 103). ${ }^{5}$

Raporun dördüncü maddesine göre bölgede bulunan suların üst kısmındaki doğal çağlayanlar ve yapay olarak oluşturulacak çağlayanlarla elektrik enerjisi elde edilmesi planlanmıştır. Bu sayede ovada ekilecek şeker kamışından şeker üretmek için tesis edilecek fabrikalar ile pamuk fabrikalarına, çeşitli sanayi tesislerine ve ziraat alanlarına daha ucuza elektrik tedarik edilecek ve dağıtılacaktır. Böylece bölgede eksik olan insan gücü, elektrik kuvveti ile telafi edilecek ve bölgeye büyük faydalar getirecektir. Çünkü Adana Ovası'nda yapılacak faaliyetlerden sağlanacak faydaların etkileri konusunda en fazla tereddüt, nüfusun az miktarda bulunmasıdır (Süleyman Sirrı, R. 1340, s. 4-5).

Çukurova 1860 'lara kadar henüz yoğun olarak tarım yapan yerleşik bir nüfusa sahip değildi. Gerek Kırım Savaşı sonrasında gerekse daha sonra Çerkez göçleriyle nüfuz biraz artırılmıştı. Bölgeye yaptırılan göçlerde en önemli gelişme Fırka-i Islahiye ile 1865 yılında yapılan iskân hareketiydi. Bu iskânlar 1890'lara kadar devam etmişti (Toksöz, 2006, s. 98-99). Adana vilayet salnamesindeki 1902 yllına ait bilgilere göre Adana nüfusu toplam 436.235 kişiden oluşmaktaydı (Hasgül, 2016, s. 73; Salname-i Vilayet-i Adana, H.1320) ${ }^{6}$ Birinci Dünya Savaşı'nın hemen öncesinde yani 1914 yllındaki verilere göre ise toplam nüfus 411.023 'e gerilemişti (Karpat, 2010, s. 400). ${ }^{7}$ Ancak bu dönemde Osmanlı Devleti'nin yaptığı savaşlar ve 1909 yılında Adana'da yaşanan Ermeni olayları nedeniyle kayıplar yaşanmıştı (Hatipoğlu, 2014, s. 2032-2033). Bu olayların ardından yaşanan Birinci Dünya Savaşı ve bu sırada çıkarılan Sevk ve İskân Kanunu ile Kurtuluş Savaşı'nda yaşanan kayıplar bölgede nüfusun azalmasına neden olmuştu. 1921 yılındaki Teşkilat-1 Esasiye Kanunu ile idari yapılanmada değişiklikler olmuş ve Adana'ya bağlı Mersin, Kozan ve Cebelibereket sancakları il statüsü kazanmıştı. Bu olayların neticesinde Adana nüfusunda sürekli değişimler gerçekleşmiştir. Tüm bunların sonucunda 1927 yllında yapılan ilk nüfus sayımında Adana nüfusu 227.718 olarak tespit edilmiştir (Çanak \& Yeşil, 2015, s. 104-106). $\mathrm{Bu}$ sebeplerle bölgede ihtiyaç duyulan insan gücü için Toros Dağları eteklerinin oldukça yüksek bulunması nedeniyle iklimi serin olduğundan, iklimi soğuk olan bölgelerden gelecek göçmenlerin buralarda iskân edilebileceği düşünülmüş̧ür. Bunlar, ekin ve orak zamanlarında ovada ikamet ettirilebilir ve iş bittikten sonra da köylerine gidebilirlerdi. Böylece göçmenlerin yavaş yavaş iklime alıştırılarak nüfusun çoğaltılması ve iş gücünün artırılması hesaplanmıştır. Ancak bu durum yukarıda zikredildiği gibi kısmen elektrik kuvvetinin teminiyle boşa çıkacak insan gücü, diğer alanlara kaydırılabilir ve ihtiyaç azaltılabilirdi. Bu sayede insan gücü ihtiyacının geçici bir süre için sorun teşkil edeceği düşünülmüştür (Süleyman Sırrı, R. 1340, s. 5). Aslında bölgedeki iş gücü ihtiyacı yerleşik ahaliyle neredeyse hiçbir zaman karşılanamamıştır. Bölgede yapılan tarımda özellikle pamuk üretiminde toprağın çapalanması ve ürünün toplanması sırasında yoğun iş gücüne ihtiyaç duyulmakta ve bu da

\footnotetext{
${ }^{4}$ Joseph Harrer, 20 Temmuz 1924 tarihinde iki arkadaşıyla birlikte yıkanmak için Seyhan Nehri’ne girmiş ve bir arkadaşıla birlikte boğularak hayatını kaybetmiștir.

5 “Aşağı Seyhan ovasının taşkından korunması ve sulaması proje çalışmaları 4 aşamaya ayrılabilir. Birinci aşamada, 27.800 hektar Yüreğir ovasında olmak üzere 65.000 hektar sahanın sulama ve drenajı, 22.000 hektar sahanın taşkından korunması sağlanmıştır. İkinci aşamada, 21.400 hektar alan Tarsus, 27.200 hektar alan Yüreğir ovasında olmak üzere 48.600 hektar alanın sulama ve drenaj çalışmaları 1974 yılında tamamlanmıştır. Üçüncü aşamada ise Tarsus ovasında 19.831 hektar alan sulamaya açılmıştır. Ayrıca 2.000 hektar alan taşkından korunan bu çalıșma, 1985 yılında tamamlanmıștır. Dördüncü așamada ise ovanın denize yakın bölümleri olup, drenaj pompajlıdır. Bu safhada 40.657 hektar alan sulamaya açılacaktır. İnşaat çalışmaları devam etmektedir. Proje tamamlandığında toplam 173.638 hektar alan sulamaya açılmış olacaktır."

${ }^{6}$ 388.927 Müslüman, 6.971 Rum, 34.291 Ermeni, 2.895 Katolik, 3.031 Protestan ve 120 Süryani-i Kadim.

7 341.903 Müslüman, 8.537 Rum, 50.139 Ermeni, 66 Yahudi, 437 Rum Katolik, 2.511 Katolik Ermeni, 5.036 Protestan, 174 Latin, 467 Süryani, 406 Keldani, 1.045 Jakobi, 302 Maruni.
} 
Osmanlı döneminde mevsimlik işçilerle karşılanabilmekteydi (Toksöz, 2006, s. 101). Aynı durum Cumhuriyet döneminde de uzun süre devam etti ve yakın zamana kadar bu iş gücü aynı şekilde karşılandı.

Raporun beşinci ve son maddesine göre mümkün mertebede ve uygun olan mevsimlerde nehir taşımacılığının temin edilmesi gerekmektedir. Bu amaçla sulama zamanıyla sınırlı olmayarak suların fazla olduğu zamanlarda Seyhan ve Ceyhan vasıtasıyla nakliyat yapılarak Mersin'e ve İskenderun limanına mahsullerin kolaylıkla nakli için nehir taşımacılığından faydalanılması düşünülmüşstür. Diğer taraftan Adana Ovası'nın deniz kenarında olması ve ovanın boydan boya demiryolu hattı ile bir taraftan Adana merkezden İskenderun Limanı'na 135 ve Mersin'e 67 kilometre kadar çok az bir mesafe ile bağlı bulunması sayesinde elde edilecek mahsullerin kolaylıkla nakli mümkündü. Ovanın Avrupa'ya yakın olması buraya bir üstünlük kazandırmaktadır. Su ve demiryolu dışında Adana Ovası düz ve yağmurun az olması dolayısıyla nakliyat için taşsız yollar yapılmaya elverişlidir. Bu yolların açılacak kanallardan çıkacak toprak ile vücuda getirilmesi mümkün olduğu gibi az bir masrafla yapılacak dekovil hatlarıyla karayolu yükünü azaltmak ve nakliyeyi kolaylaştırmak da mümkündür (Süleyman Sırrı, R. 1340, s. 4-5). Sırrı Bey'in incelemelerinde bölgenin üç tür ulaşım yöntemi için uygun olduğu ifade edilmektedir. Ayrıca ovanın coğrafi konumu da gerçekten önemli iki limana yakınlığından dolayı bölgeye avantaj sağlayacak niteliktedir. Osmanlı döneminde Seyhan Nehri'nin geniş ve küçük gemilerin hareket edebileceği kadar derin olması sayesinde bu gemiler Taşköprü’ye kadar geliyordu. Genellikle Kıbrıs ve Kuzey Suriye'den Adana'ya gelen gemiler buradan aldıkları tarım ürünlerini memleketlerine götürüyordu (Çatal, 2015, s. 291). Fakat tarım ürünlerinin taşınmasında bu tarihlerde en iyi kara ulaşım aracı şüphesiz demiryoluydu ve bu yol zaten mevcuttu. 1883 yılında Mersin-Adana Demiryolu yapımı için İngiliz bir şirkete imtiyaz verilmiş ve yol 1886 yılında tamamlanmıştı. Böylece Mersin Limanı, Adana Vilayeti'nin dünyaya açılan iskelesi haline gelmişti (Uğuz, 2016, s. 337; Akpolat 2004, s.79). Diğer taraftan Bağdat Demiryolu Şirketi, Bağdat hattı üzerinden İskenderun'a tamamen kendi imkânlarıyla bir hat açmayı teklif etmiş ve 1912 yılında başladığı Toprakkale-İskenderun hattını 1913 yılında tamamlamıştı (Beşirli, 2004, s. 226-227). Böylece Çukurova iki önemli limana entegre olmuştu. Buna karşılık Sırrı Bey'in önerdiği dekovil yolu ve suyolu hayata geçmedi. Suyolu aslında yoğun bir nakliye için uygun değildi ve karadan 67 kilometrelik yola karşılık Seyhan Nehri'nin şehirden denize uzaklığı menderesler nedeniyle yaklaşık 90 kilometreydi (Çatal, 2015, s. 293). Bu da yolu oldukça uzatmaktaydı.

\section{ISLAH ÇALIŞMALARINDAN SONRA ELDE EDİLECEK FAYDALAR}

Adana Ovası 250 bin hektardır. 50.000 hektarı tepe ve kum tepelerinden oluştuğundan sulanması mümkün değildir. Kalan 200 bin hektar arazinin 17 bin hektarı Berdan, 132 bin hektarı Seyhan ve geriye kalan 51 bin hektarı ise Ceyhan ile sulanması planlanmışıtır.

\section{Yapılacak Masraf ve Elde Edilecek Gelir}

Adana Ovası'nda yapılacak çalışmaların maliyetinin yaklaşı 3.500 .000 Osmanlı lirası tutacă̆ hesaplanmıştı. Arazinin üç yıllık devrede 1/3'üne pamuk, 1/3'üne şeker kamışı ve diğer 1/3'üne de buğday ekilmesi halinde alınacak mahsul ve elde edilecek gelir şöyledir (Süleyman Sırrı, R. 1340, s. 6).

Tablo 1. Yıllık Elde Edilecek Mahsul ve Gelir Miktarı ${ }^{8}$

\begin{tabular}{|c|c|c|c|c|c|c|c|}
\hline $\begin{array}{c}\text { Mahsulün } \\
\text { Cinsi }\end{array}$ & $\begin{array}{c}\text { Ekilen } \\
\text { Arazi }\end{array}$ & $\begin{array}{c}\text { Her } \\
\text { Dönümden } \\
\text { Alınan Mahsul }\end{array}$ & $\begin{array}{l}\text { Toplam } \\
\text { Mahsul }\end{array}$ & $\begin{array}{c}\text { Her Kilonun } \\
\text { Ortalamasi }\end{array}$ & Toplamı & $\begin{array}{l}\text { 12,5'den } \\
\text { Vergisi }\end{array}$ & Vergi \\
\hline & Dönüm & Kilo & Kilo & Kuruş & Kuruș & Kuruş & Osmanlı Lirası \\
\hline Buğday & 725.253 & 400 & 290.101 .200 & 0,70 & 203.070 .840 & - & - \\
\hline Pamuk & 725.253 & 50 & 36.262 .650 & 7,8 & 282.848 .670 & - & - \\
\hline $\begin{array}{l}\text { Pamuk } \\
\text { Tohumu }\end{array}$ & & 60 & 43.515 .180 & 0,33 & 14.360 .009 & - & - \\
\hline \multirow[t]{2}{*}{$\begin{array}{l}\text { Şeker } \\
\text { Kamışı }\end{array}$} & 725.253 & 6.000 & 4.351 .518 .000 & 0,075 & 326.363 .850 & - & - \\
\hline & $2.175 .760^{9}$ & & & & 826.643 .369 & 103.330 .421 & 1.033 .304 \\
\hline
\end{tabular}

Adana Ovası'nın, sulandığında ve tamamen ekilmesi halinde yıllık 8.266.433 Osmanlı lirası değerinde mahsul alınacağı ve bundan hükümetin hissesine aşar adıyla gayr-i safi hasıla üzerinden 1.033.304 Osmanlı lirası

\footnotetext{
${ }^{8}$ Raporda bazı toplama hataları yapıldığından tabloda rakamlar düzeltilmiştir.

${ }^{9}$ Günümüz ölçü birimlerine göre 1 hektar=10 dönüme karşıllk gelmektedir. Fakat o tarihlerde 1 dönüm=919,3 m² 1 Hektar=10,88 dönüm olarak hesaplanmaktadır. Bu nedenle raporda verilen 200.000 hektar 2.176.000 dönüm şeklinde hesaplanmıştır (Güran, 1997, s.XIX).
} 
gelir sağlayacağı hesaplanmıştır. Ayrıca her dönümün ortalama gayr-i safi hasılası 826.643.369/2.175.760=380 kuruş olacaktır. Bununla birlikte elde edilmesi planlanan gelirler şöyledir.

1- Gayr-i safi hasılat vergisinden hükümetin geliri 1.033.304 Osmanlı lirası.

2- Arazi sahipleri arasında dağıtılan ve tamirat masrafları ile sulama kirası olarak alınacak miktar, inşa masraflarının yüzde ikisi 0,02 X 3.500.000 = 70.000 Osmanlı lirası.

3- Sulanacak ve kurutulacak araziden faydalanacak ahaliye sermayenin bir kısmını azar azar ödemesi için konulacak yıllık taksit 0,04 X 3.500.000 = 140.000 Osmanlı lirası.

Bu hesaba göre, ıslah çalışmaları neticesinde ülkenin yıllık geliri 1.243.304 Osmanlı lirası olacaktır.

Islah çalışmaları için harcanacak 3.500.000 Osmanlı lirasının 35 yıllık taksitle geri ödenmesi planlanmıştır. $\mathrm{Bu}$ paranın yıllık taksiti 227.500 Osmanlı lirası olduğundan faiziyle birlikte geri ödenecek toplam tutar 7.962.500'ü bulmaktadır. Ayrıca sulama ve sürekli tamirat ücreti de 70.000 liradır. Böylece toplam yıllık masraf 297.500 liraya ulaşmaktadır. Toplam arazinin ekilmesi durumunda yukarıdaki hesaplamaya göre 1.243.304 lira olan yıllık toplam gelirden 297.500 lira yıllık toplam masraf çıkarıldığında hükümetin elde edeceği gelir 945.804 lira olarak gerçekleşecektir (bk. Ek 1).

Yapılacak ıslah çalışmaları yukarıda da ifade edildiği üzere bir anda gerçekleşmeyecek olup, arazinin tamamen sulaması peyderpey yapılacaktır. Bu nedenle arazinin ilk yıllarda tamamen ekilmesi hem sulamadan hem de nüfus azlığından dolayı mümkün değildir. Muhacirlerin iskânı ile nüfusun çoğaltılması sonucunda tüm arazinin ancak 25 sene zarfinda ekilebileceği tahmin edilmektedir. Bu plan çerçevesinde her 5 yılda tüm arazinin 1/4'ünün sulu tarıma geçmesi planlanmıştır. Buna göre de ilk yirmi yıl içinde ortalama yıllık gelir 590.625, 20. yıldan 35. yıla kadar 945.000 ve 35. yıldan sonra da 1slah çalışmaları için harcanan paranın taksitleri biteceğinden 1.172.500 Osmanlı lirasına ulaşacağı düşünülmektedir (bk. Ek 1).

Doğrudan vergi yoluyla elde edilecek gelirler dışında Adana Ovası'nda üç yıllık devre ile her yıl 4.351.518 ton şeker kamışı elde edileceği hesaplanmıştır. Bunun \%2,3 oranındaki tortusunun dışında \%10,4 nispetinde süzülmüş saf şeker üretildiğinden, yaklaşık her yıl 453.000 ton şeker elde edilebilir. Sırrı Bey’e göre Osmanlı Devleti'nde her yıl sarf olunan şeker 110.000 tondan ibarettir. Bu her ihtimale karşı 200.000 ton kabul edilse dahi elde edilecek miktar ülke ihtiyacını karşıladığı gibi 253.000 tonu ihraç edilebilecektir. Bu sayede daha önce ithal edilen şeker bu defa ihraç edilecek ve içeride tüketilecek şekerin bedeli olan birkaç milyon lira memlekette kalacaktır (Süleyman Sırrı, R. 1340, s. 6-8).

\section{Çiftçiden Alınacak Vergi Miktarı ve Çiftçinin Net Geliri}

Adana Ovası'nın sulanması 210.000 liralık bir bütçe gerektirmektedir. Sulama gideri ve inşa masraflarına harcanacak bu bütçe vergi ile karşılanabilecektir. Vergi yükü toplam araziye paylaştırıldığında dönüm baş1 9.65 kuruş vergi toplanmasına ihtiyaç vardır. Bu yatırım ovanın kıymetini ve çiftçinin kazancını artıracaktır. Yapılan hesaplamaya göre ekilecek mahsulden çiftçinin elde edeceği net gelir şöyledir (Süleyman Sırrı, R. 1340, s. 8):

Tablo 2. Her Dönüme Karşılık Gelen Gelirler ve Masraflar İle Net Gelir Miktarı.

\begin{tabular}{|c|c|c|c|c|c|c|c|c|}
\hline Mahsulün Cinsi & $\begin{array}{l}\text { Mahsul } \\
\text { Miktarı }\end{array}$ & $\begin{array}{c}\text { Kilosunun } \\
\text { Fiyatı }\end{array}$ & $\begin{array}{c}\text { Gayr-i } \\
\text { Safi Gelir }\end{array}$ & $\begin{array}{l}\text { Üretim } \\
\text { Masrafi }\end{array}$ & $\begin{array}{c}\text { Sulama Ücreti } \\
\text { ve Yıllık Taksit }\end{array}$ & $\begin{array}{l}\text { \% } 12,5 \text { 'den } \\
\text { Aşar Vergisi }\end{array}$ & $\begin{array}{l}\text { Net } \\
\text { Gelir }\end{array}$ & $\begin{array}{l}\text { Ortalama } \\
\text { Net Gelir }\end{array}$ \\
\hline & Kilogram & Kuruş & Kuruş & Kuruş & Kuruş & Kuruş & Kuruş & Kuruş \\
\hline Buğday & 400 & 0,70 & 280 & 65 & 9,65 & 35 & 170,35 & \multirow{4}{*}{190} \\
\hline Pamuk & 50 & 7,8 & 390 & 130 & 9,65 & 48,75 & 208,13 & \\
\hline Pamuk Tohumu & 60 & 0,33 & 19,8 & 9,8 & 0 & 2,47 & 0 & \\
\hline Şeker Kamışı & 6000 & 0,075 & 450 & 190 & 9,65 & 56,25 & 194,10 & \\
\hline
\end{tabular}

Bu verilere göre çiftçiler her dönümden ortalama 190 kuruş net gelir elde edeceklerdi. Yukarıda ifade edildiği üzere her dönümün ortalama gayr-i safi geliri 380 kuruştu. Bunun \%12,5'den aşar vergisi ve sulama ücreti ile y1llık taksit adıyla çiftçiye yüklenen vergi 57,15 kuruştan ibaretti. Bu miktar gayr-i safi gelirin \%15'ine denk gelmektedir. Her dönümün 190 kuruşa karşılık gelen ortalama net gelirine nazaran alınan vergi miktarı oldukça azdır. Bu nedenle Süleyman Sırrı Bey, çiftçinin net geliri üzerinden ayrıca bir vergi alınmasını da teklif etmiştir. Teklif ettiği oran ise net gelirin \%10'uydu. Bu hesaba göre elde edilen 4.139.435 Osmanlı lirası net gelirin yüzde onu 413.943 liraydı (bk. Ek 2). Bu sayede ek bir gelir daha temin edilmiş olacaktı. Bu yeni vergi ile birlikte 35 . yıldan sonra gayr-i safi gelir ile birlikte devletin net geliri 1.586.433 Osmanlı lirasına ulaşacaktır. Sırrı Bey, bu sayede hükümete önemli bir gelir daha sağlanacağını ve yıllık yaklaşık 4.140.000 lira net gelir sağlayan çiftçilerin bu meblağın onda birini hükümete memnuniyetle vereceklerini farz ediyordu. Ayrıca projenin gerçekleşmesi durumunda ileride ziraatın sanayiye tatbikiyle Adana Ovası, gelişmiş bir yer olacaktı. Burada 
kurulacak fabrikalar ve çeşitli müesseseler ile yeni köyler oluşacak ve bunlardan emlâk vergisi alınacağından yine bir gelir temin edilmiş olacaktır (Süleyman Sırrı, R. 1340, s. 7-10).

Sırrı Bey, Adana Ovası'nın ıslahı sonucunda devletin büyük bir gelir elde edeceğini rakamlarla ortaya koymaya çalışmıştır. Fakat devlet gerçekten de yapacağı harcamalar sonucunda böyle bir kazanç sağlayabilir miydi? Çalışmasında kendisi de hâlihazırda ovanın sulanacak kısmında ekilen arazi miktarı bilinemediğinden hesaplamaların toplam alan üzerinden yapıldığını ifade etmiştir. O halde bahsedilen yaklaşık 200.000 hektarlık arazi ilk kez tarıma açılan bir yer olmayıp zaten tarım faaliyetinin gerçekleştiği bir alandı. Hatta tüm Çukurova hesaba katıldığında Berdan Çayı-Ceyhan Nehri arası tarım faaliyetlerinin en yoğun yapıldığı bölgeydi. Bu nedenle ıslah çalışmasının gerçek getirisini anlamak için bölgede hâlihazırda yapılan tarım faaliyetlerine bakmak gerekmektedir. Bunun için de Osmanlı'nın son döneminde bölgenin üretim faaliyetlerine bakmak, durumun tespiti açısından önemlidir.

Sırrı Bey, raporunu "üç beyaz" ürün üzerinden oluşturduğundan öncelikle bu ürünlerin üretim durumuna bakmakta fayda vardır. İlkçağlardan itibaren tüm dünyada kabaca 32-35 derece güney ile 37 derece kuzey enlemleri arsında kalan bölgelerde pamuk üretimi yapılmaktadır (Beckert, 2018, s. 27). Çukurova Bölgesi de ilk çağlardan itibaren pamuk ekimi yapılan bir bölgedir. Ancak bu üretim 1820'lere kadar yöresel ihtiyac1 karşılayacak düzeyde kalmıştı (Yaktı, 2013, s. 275). Bu tarihlerden itibaren Kıbrıs ve Mısır'dan getirilen kaliteli pamuk tohumları ve yeni ekim teknikleriyle artan üretim 1950'lerde 50 bin balyaya ulaşmıştı (Doğan \& Ünal, 2011, s. 5). Bölgede ekilebilir tarım arazileri 19. yüzyılın ortalarından itibaren başta pamuk ekilen araziler olmak üzere genişlemeye başladı. Osmanlı Devleti pamuk üretimini teşvik etmek amacıyla 1862 yılında 5 yıl süreyle üreticilere vergi kolaylığı verilmesi ve tohum sağlanması için bir ferman yayımlamıştı. Bölgede, tarım alanlarındaki canlanma 1870'lerde görüldü ve topraklar hızla üretime açılmaya başlandı. Kısa bir sürede büyük tarım arazileri Çukurova ile özdeşleşmeye başladı. Adana-Tarsus arasındaki bataklıkların 1870'lerde büyük oranda kurutulması ve 1890'larda da Adana-Ceyhan arasındaki toprakların da tarıma açılmasıyla Çukurova'da büyük ölçekte pamuk üretimi gerçekleşti. Bu tarihlerde bölgedeki ekilebilir arazilerin yaklaşık 2/3'ünde pamuk üretimi yapılmaktadır. Pamuk üretimi 19. yüzyılın son on yılında yaklaşık iki katına çıkmıştır (Toksöz, 2006, s. 107). ${ }^{10}$ İstatistik verilerine göre 1913 yılında ${ }^{11}$ pamuk üretimi ülke genelinde 1.619 .429 dönüm olarak gerçekleşmiştir. Adana 829.690 dönümle ülkede ekilen toplam pamuk arazisinin yaklaşık yarısına sahipti. Ülke genelinde üretilen toplam 57.138 ton pamuğun 27.072 tonu yine Adana'da üretiliyordu (Güran, 1997, s. 117120). ${ }^{12}$ Fakat iklimin etkisinden dolayı ekilen pamuklar erken bir dönemde yani Şubat ayında ekildiğinden ve yağmurların da etkisiyle kirlendiğinden, iyi cins pamuk elde edilememektedir. Hâlbuki üretimin, arazinin sulanarak yapıldığı yerlerdeki tecrübelere göre, Mısır ve Amerikan pamuk türlerinin ıslah edilmesiyle orta derecede fidan uzunluğuna sahip, elyafının mukavemeti ve ipeksiliği iyi ve çok iyi derecede pamuk yetiştirilmesi mümkündür (Süleyman Sırrı, R. 1340, s. 3).

Buğday üretimine bakıldığında, Osmanlı'nın klasik döneminde özellikle İstanbul'un hububat ihtiyacı büyük oranda Balkanlardan ve Ege sahillerinden karşılanmaktadır. Anadolu'daki tarım arazilerinin yaklaşık \% 090 'ında kuru tarım yapılmakta ve hububat ekilmektedir. Bu üretim de kırsal kesimin kendi ihtiyaçları ve ulaşım sıkıntısından dolayı yerel pazarlar için yapılmaktadır. 19. yüzyıla gelindiğinde ise genişleyen pazarla hem daha geniş araziler tarıma açılmış hem de dış pazar için üretim artmıştır (Pamuk, 2003, s. 37-38, 214). Ancak hububat üretiminin artmasına rağmen 1914 yılında Osmanlı Devleti hâlâ un ihtiyacının büyük bir kısmını Romanya, Rusya ve Marsilya'dan karşılamaktadır (Toprak, 1978, s. 211). Buna karşıllık Anadolu'nun birçok kenti, ihtiyacının altında üretim yapsa da Adana bölgesinde yapılan hububat üretimi oldukça fazladır. Adana, 1913 yılındaki verilere göre tüm Anadolu şehirlerinde buğday ekilen arazi bakımından $682.118^{13}$ dönüm ile 13. sırada, elde edilen toplam ürün bakımından $135.530^{14}$ ton ile 7 . sırada ve hektar başına elde edilen ürün miktarı bakımından da $2.162^{15} \mathrm{~kg}$ ile 5. sırada bulunmaktadır (Güran, 1997, s. 87-96). Ayrıca alan olarak Adana'dan

\footnotetext{
${ }^{10}$ Çukurova bölgesinde pamuk yetiştirmek amacıyla yerli yatırımcıların dışında yabancı yatırımcılar da bulunmaktaydı. 1912 yılında Fransa, Ceyhan-Adana arasında yaklaşık 72 bin hektarı bulan bir alanı işletmek için Osmanlı ile bir kontrat imzaladı. Fakat Bağdat Demiryolu'na yakınlığı nedeniyle Almanya'nın itirazı üzerine bu kontrat tek taraflı feshedilmiști.

111913 tarım istatistiğinde Adana Vilayeti'ne bağlı olan yerler: Karaisalı, Yumurtalık, Ceyhan, Osmaniye, Islahiye, Bahçe, Hassa, Dörtyol, Kozan Saimbeyli (Haçin), Feke ve Kadirli’den (Kars) oluşmaktaydı.

${ }^{12}$ Adana'dan sonra en çok ekim yapılan yer 423.840 dönüm ile İçel'dir.

${ }^{13}$ Konya 2.553.719, Ankara 2.388.287, Sivas 1.367.965, Kırşehir 1.309.900, Kütahya, 1.250.000, Diyarbakır 1.031.586, Balıkesir 927.100, Tokat 884.855, Yozgat 880.500, Antalya 818.081, Niğde 737.687 ve Afyon 712.400 dönüm.

${ }^{14}$ Konya 535.887, Ankara 319.901, Sivas 205.772, Kırşehir 184.961, Yozgat 142.832 ve Niğde 138.438 ton.

${ }^{15}$ İzmir 2.733, Sinop 2.359, Konya 2.283 ve Isparta $2.211 \mathrm{~kg}$.
} 
daha fazla ekim yapılan iller arasında hektar başına $2.283 \mathrm{~kg}$ ile sadece Konya vardır. Bu veriler göstermektedir ki Adana hem toprağın verimliliği hem de ülkenin buğday ihtiyacını karşılaması bakımından önemli bir bölgedir.

Sırrı Bey, pamuk ve buğday dışında bölge çiftçilerine büyük kazanç sağlayabilecek şeker kamışının, çok daha fazla üretilebilecekken, bu üretimin sınırlı miktarda kaldığını ifade etmektedir. Çünkü bitkinin düzenli olarak Ağustos sonuna kadar 10 günde bir, Aralık sonuna kadar ise 15-20 günde bir sulanması gerekirken bu yapılamamaktadır (Süleyman Sırrı, R. 1340, s. 3). Osmanlı döneminde şeker imali için gereken ham madde İç Anadolu ve Doğu Anadolu'daki bazı illerde ziraatı yapılan şeker pancarından karşılanmaktadır. Şeker kamışı üretimi için ise 19. yüzyılın sonlarında bu ürünün yetiştirilebileceği bölgeler araştırılmıştır. Bu bölgelerin başında da Çukurova Bölgesi gelmektedir. Ürünün yetiştirilebilmesi için 1870 yllında Dahiliye Nezareti'nden bir miktar tohum, ekim şeklini anlatan bilgi notları ve bu işten anlayan bir görevlinin Adana'ya gönderilmesi talep edilmiş̧ir. Bu tarihten sonra bölgede yaygınlaşmaya başlayan şeker kamışı üretimi neticesinde 1898 yılında Adana'da şeker fabrikası kurma girişimi gerçekleştiği gibi 10.000 dönüm arazide yapılacak şeker kamışı ve pancarının öşür vergisinden muaf tutulmasına da karar verilmiştir (Karayaman, 2010, s. 300, 312). Fakat fabrika kurma girişimleri sonuçsuz kalmıştır. Çünkü şeker kamışı üretimi istenilen ölçüde yaygınlaşamamıştır (Özer, 2021, s. 97). Bu nedenle 1913 yılı istatistiklerinde Adana'da sadece 120 dönümde yapılan pancar ziraatından 22 ton ürün elde edilirken, şeker kamışı üretimine dair bir veri bulunmamaktadır (Güran, 1997, s. 107-109). Cumhuriyet Döneminde ise 1930'lu yıllarda Adana'da şeker kamışından şeker üretimi yeniden gündeme gelmiştir. Ardından 1943 yılında yapılan tetkikler neticesinde bu bölgede 50.000 ton şeker üretilebileceği tespit edilse de köylü açısından pancarın daha kârlı olması ve savaş yıllarının getirdiği sıkıntılardan dolayı bu ürün yaygınlık kazanamamıştır (Özer, 2021, s. 119 ).

Sırrı Bey, raporunu o dönemde en önemli ve asıl gelir sağlayan ürünler olması nedeniyle hesaplamaları üç beyaz olarak tanımlanan buğday, pamuk ve şeker kamışı üzerinden yapmıştır. Bunlarla beraber ovada yetiştirilebilecek ve önemli miktarda gelir sağlayacak başka ürünlerin de olduğu ifade edilmiştir. Bu ürünler ve bunların 1913 yılı istatistiğine göre üretim miktarı ise şöyledir (Süleyman Sırrı, R. 1340, s. 9; Güran, 1997, s. 87134; Bkz. Ek 3):

1- Denize yakınlığından dolayı oldukça çukur ve tuzlu bulunan ve bataklık halinde kalacak olan arazide ancak pirinç üretilebilirdi. Bu mahsul de pamuk ve şeker kamışı kadar kazançlı bir üründü. Adana'da bu ürünün ziraatı istatistiğe göre 900 dönümlük arazide yapılmakta ve yıllık 143 ton üretilmekteydi.

2- Zeytin Adana Ovası'nda sulanmak şartıyla, altı yedi senede mahsul vermekteydi. Bu durumda arazinin önemine göre farklı mahsul vermeye müsait olmayan veyahut yüksekliği bakımından ancak tahrik kuvvetiyle sulanabilecek yerlerde zeytin yetiştirilerek bundan iyi bir gelir elde etmek mümkündür. O tarihte Adana'da ticari amaçlı zeytin ekimi yapılmamaktadır.

3- Limon, portakal, badem vesaire meyveler bol miktarda yetiştirilebilirdi. İstatistikte Adana'da yetiştirilen meyveler incir, elma, armut, erik, kayısı, nar, dut, portakal, limon, badem ve cevizdi. Bunlardan yıllık 8.427 ton ürün elde ediliyordu.

4- Sebze yine iyi ve bol miktarda yetiştiği gibi ovada sanayi geliştikçe bunlardan konserve vesaire imal edilerek ayrıca gelir elde edilebilirdi.

Buğday ve pirinç dışında ovada yetişen hububat, toplam 659.708 dönümde ziraatı yapılan kaplıca (kızıl buğday), arpa, yulaf, mısır, darı, kuşyemi ve çavdar olmak üzere bunlardan toplam 80.431 ton ürün elde ediliyordu. Sanayi bitkilerinden pamuk dışında toplam 285.519 dönümde başta susam olmak üzere keten ve tütün yetiştirilmekte ve yıllık toplam 9.880 tonluk üretim yapılmaktaydı. Baklagillerden toplam 28.239 dönüme ekilen bakla, bezelye, nohut, fasulye, mercimek ve burçaktan y1llık toplam 3.360 ton ürün elde edilmekteydi. Son olarak köklü bitkilerden ise toplam 13.483 dönüme patates, pancar, havuç, soğan ve sarımsak ekilmekte ve yıllık toplam 2.300 ton ürün alınmaktaydı. Ayrıca 145.740 dönümde de üzüm yetişmekte ve yıllık 15.414 ton mahsul yetiştiriliyordu. Bunların dışında muhakkak ki bölgede halkın günlük sebze ihtiyacına yönelik her nevi sebze yetiştirilmekteydi. Fakat bunlar muhtemelen büyük çapta yapılmadığından istatistikte yer almamıştır.

5- O günkü şartlarda bataklık yerlerde çayır ekiliyordu. Ancak bölge sulandıktan sonra istenilen yerlerde en iyi çayırlıklar tesis edilerek hem toprağın dinlendirilmesi sağlanmış olacak hem de üretim masrafları diğer mahsullere nispetle pek az olan çayır ve yoncadan tamamen istifade temin edilebilecekti. Böylece hayvanlar iyi beslenerek ihracattan önemli kazançlar sağlanabilecekti.

Tüm verilere bakıldığında 1913 yılında Adana'nın genelinde toplam 243.060 hektarlık alanda ziraat yapılmaktaydı. İstatistikte Adana'nın genelinde yapılan ziraata karşılık Sırrı Bey, Berdan Çayı-Ceyhan arasındaki yaklaşık 200.000 hektarlık alanda yapılacak ziraatı temel almaktadır. Ancak Ceyhan Nehri'nin doğusu ile Berdan Çayı'nın batısında İçel'e kadar olan bölgede verimli araziler bulunurken asıl üretimin 
özellikle pamuk üretiminin yapıldığı bölgenin Adana Ovası olarak tanımlanan bu alanda gerçekleştiği ve bu nedenle 1913 yılında tarım yapılan toplam arazinin yarısının dahi bu bölgede yapıldığı farz edilse bile hâlihazırda yaklaşık 120.000 hektarda ziraat faaliyetinin yapıldığı rahatlıkla söylenebilir. Diğer taraftan yine sulama neticesinde bölgede dönümden $400 \mathrm{~kg}$. olmak üzere 290.101 ton buğday ve yine dönümden $50 \mathrm{~kg}$. olmak üzere 36.262 ton pamuk üretilmesi hedeflenmiştir (bk. Tablo 1). İstatistiğe göre ise 1913 yllında dönümden 198 kg. olmak üzere toplam 135.530 ton buğday ve her dönümden $32 \mathrm{~kg}$. olmak üzere toplam 27.072 ton pamuk üretimi yapılmaktadır. Hesaplamalar sulama sayesinde elde edilecek ürün miktarının iki katına çıkacağı yönündeydi ki günümüzde bölgede dönümden elde edilen mahsul bu rakamların da üzerindedir. Ayrıca Adana Vilayeti'nin tamamında üretilen pamuk ve buğdaydan 2.577 .430 olmak üzere tüm üretimden elde edilen gelir 3.373.440 liraydı. Bölgede şeker kamışı üretimi gerçekleşmediği için projenin hayata geçmesi sonucunda sadece buğday ve pamuktan elde edilmesi hedeflenen gelir ise 4.859.194 liraydı. Bu hesaplar göstermektedir ki sadece sulanması planlanan arazinin 2/3'ünden elde edilecek gelir dahi 1913 y1lında vilayetin tamamından elde edilen gelirden yaklaşı $\% 50$ daha fazladır. Başka bir deyişle sulama projesinin hayata geçmesi neticesinde sadece Adana Ovası olarak adlandırılan bölge, daha önce vilayetin tamamında yapılan üretimden ve gelirden çok daha fazla bir kazanç sağlayabilirdi.

\section{SONUC}

İzmir İktisat Kongresi sonucunda ortaya çıkan düşünceler doğrultusunda ülkenin ithal ettiği tarım ürünlerinin yerli üretimle karşılanması ve bundan kaynaklanan döviz çıktısının azaltılması amaçlanmıştı. Bunun için Cumhuriyet'in ilk Nafia Bakanı Süleyman Sırrı Bey, üç beyaz olarak adlandırılan buğday, pamuk ve şeker üretiminin artırılması amacıyla Adana Ovası'nın ıslahı için bir proje hazırladı. Ülkenin içinde bulunduğu ekonomik durumu ve iktisadi politikasını yansıtması açısından önemli bir girişim olan bu proje, ovanın sorunlarını tespit etmekle birlikte ağırlıklı olarak elde edilecek kazançta yoğunlaşmışır. Bu yüzden çalışmanın belki de en büyük eksikliği hâlihazırda gerçekleşen üretimin araştırılmamış ve sorunların nasıl giderileceği hakkında tafsilata yer verilmemiş olmasıdır. Bu durum Sırrı Bey'in ülkenin ihtiyaç duyduğu acil nakit ihtiyacının karşılanması için süreçten ziyade sonuca odaklandığını göstermektedir. Çalışmanın gerçekleşmesi halinde elde edilecek gelirin ülke ekonomisi için faydalı olacağı Osmanlı'nın son dönemindeki verilerle karşılaştırıldığında açıkça anlaşılmaktadır. Fakat proje hayata geçememiştir. Projede görüldüğü üzere faaliyete nereden başlanacağının daha sonra yapılacak incelemeler neticesinde karara bağlanacağı saptanmış, ancak Sırrı Bey'in kısa bir süre sonra hayatını kaybetmesi bu girişimi sonuçsuz bırakmıştır. Bunun dışında projenin hayata geçmemesinin belki de en önemli nedeni çalışmaların ciddi bir maliyet içermesi ve bunun borçlanmayla yapılacak olmasıdır. Oysa savaştan yeni çıkmış olan ülkenin ekonomisi buna müsait değildir. Ağır aksak da olsa ülkede tarımın yapılmasına karşın sanayi tesisleri oldukça yetersizdir ve sanayi tesisleri olmadan tarım üretiminin artması tek başına ülkeye istenilen faydayı sağlamayacaktır. Bu nedenle ülkenin kalkınması yöneticiler açısından sanayi yatırımlarını desteklemek ile mümkün görünmektedir. Bunların dışında Cumhuriyetin ilk yıllarında yapılan girişimler istenilen boyutta gerçekleşememiştir. Bunda ülkenin içinde bulunduğu ekonomik durum, yaşanan isyanlar, iç ve diş siyasi olaylar ve savaşlar gibi nedenler etkilidir. Bölgede yapılan tarımsal faaliyetten istenilen fayda ancak 1956 yılında yapılan baraj ve sulama projelerinin hayata geçirilebilmesiyle mümkün olabilmiş ve eski yöneticilerin de takdir ettikleri gibi Adana Ovası ülkenin en önemli tarım merkezlerinden biri haline gelmiştir.

\section{KAYNAKLAR}

Akpolat MS (2004). Tanzimat sonrası Osmanlı mimarlığından bir kesit: Adana-Mersin demiryolu istasyon binalar1. Hacettepe Üniversitesi Edebiyat Fakültesi Dergisi, 21(1), 77-93. https://dergipark.org.tr/tr/pub/huefd/issue/41195/508496

Atatürk'ün Söylev ve Demeçleri. (1997). C.II. Türk İnkılap Tarihi Enstitüsü Yayınları.

Başkanlık Osmanlı Arşivi, BOA, DH.İD., 80/26-3; BOA, DH.MKT., 263/13; BOA, DH.MKT., 423/30; BOA, BEO., 3705/277845; BOA, Y.PRK.UM., 46/3; BOA, Y.A.HUS., 505/42; BOA, HRT.h. 2424; BOA, HRT.h. 2042; BOA, MV, 120/23; BOA, MV., 132/94.

Beckert S. (2018). Pamuk imparatorluğu, Ali Nalbant [Çev.]. Say Yayınları. 
Çukurova Üniversitesi Sosyal Bilimler Enstitüsü Dergisi, Cilt 30, Sayı 3, 2021, Sayfa 206-222

Beşirli M. (2004). Bağdat Demiryolu'nun Akdeniz uzantısı: Toprakkale-İskenderun demiryolu. A.Ü. Türkiyat Araştırmalarl Enstitüsü Dergisi https://dergipark.org.tr/tr/pub/ataunitaed/issue/2862/39084

Büyükyıldırım G. (2009) Türkiye'de su mühendisliğinin öncüsü, Türkiye Cumhuriyeti’nin 2. Bayındırlık Bakanı Süleyman Sırrı. Türkiye Mühendislik Haberleri, (453), 36-39.

Çanak E. (2015). Cumhuriyet döneminde Adana (Seyhan)'da meydana gelen seller ve alınan önlemler (19301956). CBÜ Sosyal Bilimler Dergisi, 13(1), 296-341.

Çanak E. \& Yeşil A. (2015). Atatürk döneminde Adana (Seyhan) vilayetinin demografik yapısı. Tarihin Peşinde-Uluslararası Tarih ve Sosyal Araştırmalar Dergisi, (14), 101-128.

Çatal AC (2015). Nehirlerin sosyo-ekonomik yaşantıya etkisi (Seyhan nehri örneği). Osmanlı Devletinde Nehirler ve Göller [haz.: Şakir Batmaz \& Özen Tok]. Not Yayınları, 291-300.

Doğan O. (2009) Atatürk ilkeleri ve inkllap tarihi. Fa Ajans.

Doğan O. \& Ünal EF (2011). Çukurova'ya bereket getiren projeler. Çamlıca Basım Yayın.

Güran T. (Haz.) (1997). Osmanl dönemi tarım istatistikleri 1909, 1913 ve 1914. Devlet İstatistik Enstitüsü Matbaasi.

Haktan O. (1998). Atatürk'ün ekonomi politikası; ulusal bağımsızlık ve ekonomik bağımsızlık. H. ̈̈. Edebiyat Fakültesi Dergisi. 75. Y1l Özel Sayıs1, 29-36. https://dergipark.org.tr/tr/pub/huefd/issue/42279/506996

Hasgül S. (2016) Salnâmelere göre Adana vilâyetinin demografik ve kültürel yapısı (Adana merkez, Kozan, Cebel-i Bereket, Içel ve Mersin sancă̆l). [Mersin Üniversitesi, Yüksek Lisans Tezi].

Hatipoğlu S. (2014). Doğu sorunu kapsamında Adana Ermeni olayları. Ermeni Özel Sayısı, Cilt 3, Yeni Türkiye, 2022-2038.

Iklim Sinıflandırmast Adana. https://www.mgm.gov.tr/iklim/iklim-siniflandirmalari.aspx?m=ADANA, (10.08.2021).

İnan, A. (1989), İmir iktisat kongresi. TTK Yayınları.

Karayaman M. (2010). Osmanlı Devleti’nde şeker fabrikası kurma teşebbüsleri. Tarih İncelemeleri Dergisi, 25(1), 297-318.

Karpat, KH (2010). Osmanlı Nüfusu 1830-1914. Timaş Yayınları.

Nafia Nezareti'nden Çevre ve Şehircilik Bakanlı̆̆ına Görev Yapmış Bakanlarımız(1848 - ...), https://webdosya.csb.gov.tr/db/turkce/eskibakanlar/dergi/mobile/index.html. (10.03.2021)

Ökçün AG (1981). Türkiye iktisat kongresi 1923-İzmir haberler-belgeler-yorumlar. AÜSBF Yayınları.

Öksüz M. (2016). Amerikan belgelerine göre Mondros Mütarekesi’nden 1929 Dünya Ekonomik Buhranı'na Kadar Türkiye'de para politikası. Atatürk Yolu Dergisi, (58), 195-244. https://dergipark.org.tr/tr/pub/ankuayd/issue/42482/511733

Özer S. (2021). Türkiye’de Şeker Sanayisi (1925-1950). CTAD, (33), 95-124. 
Çukurova Üniversitesi Sosyal Bilimler Enstitüsü Dergisi, Cilt 30, Sayı 3, 2021, Sayfa 206-222

Özgün C. (2013). Osmanlı ağaç kültüründe yeni ve egzotik bir tür: Okaliptüs. Çağdaş Türkiye Tarihi Araştırmaları Dergisi. 13(26), 5-29.

Pamuk Ş. (2003). Osmanll-Türkiye iktisadi tarihi 1500-1914. İletişim Yayınları.

Resmi Istatistikler. https://www.mgm.gov.tr/veridegerlendirme/il-ve-ilceler-istatistik.aspx?m=ADANA, (10.08.2021).

Salname-i Vilayet-i Adana. (1902). Defa 12, Adana Vilayet Matbaas1.

Süleyman Sırrı (R. 1340). Adana Ovası. Yeni Gün Matbaası.

TBMM Albümü 1920-2010. (2010). C.1. TBMM Basın ve Halkla İliskiler Müdürlügü Yayınları.

TBMM Zabut Ceridesi. 7/1, 18. Birleşim. 22.03.1340 Cumartesi (22 Mart 1924), 895, 949.

TMMOB İnşaat Mühendisleri Odası. (2006). “Aşağı Seyhan Sulama Projesi, Şanlıurfa Sulama Tünelleri, Yenikapı Atıksu Önarıtma Tesisi, Adana Hacı Sanabcı OSB Su Alma ve Arıtma Tesisi, Büyük İstanbul İçmesuyu II. Merhale Projesi Yeşilçay Sistemi”, Türkiye Mühendislik Haberleri, (442-443), 102-111.

Toksöz M. (2006). Bir coğrafya, bir ürün, bir bölge: 19. yüzyılda Çukurova. Kebikeç, (21), 97-110. https://kebikecdergi.files.wordpress.com/2012/07/07_toksoz.pdf

Toprak Z. (1978). Cihan Harbi yıllarında İttihat ve Terakki’nin iaşe politikası. Boğaziçi Üniversitesi Beşeri Bilimler Dergisi, 6, 211-225.

Tulga D. \& Parlayan A. (2009). Atatürk’ün Soyağac1. NTV Tarih Dergisi. (10), 24-25.

Türker AH (2008). Tarsus-Karabucak okaliptüs işletmeciliğiyle civar bölge tarımının ekonomik yönden bir kıyaslaması. I. Ulusal Okaliptüs Sempozyumu. Tarsus. 250-258.

Uğuz S. (2016). Mersin limanında ticaret (1870-1912). Mustafa Kemal Üniversitesi Sosyal Bilimler Enstitüsü Dergisi. 13(33), 334-363. https://dergipark.org.tr/tr/download/article-file/183477

Yaktı Ö. (2013). Amerikan iç savaşı ve Adana: Pamuk tarımının Adana'nın modernleşme sürecine etkisi. A. Türk Inkılâp Tarihi Enstitüsü Atatürk Yolu Dergisi, (54) 273-296. https://dergipark.org.tr/tr/download/article-file/618765

Yurtsever C. (2018). Bir Zamanlar Adana. Heyamola. 
Çukurova Üniversitesi Sosyal Bilimler Enstitüsü Dergisi, Cilt 30, Sayı 3, 2021, Sayfa 206-222

\section{EKLER}

EK 1. Devletin Kademeli Olarak Elde Edeceği Ortalama Gelir Miktarı

\begin{tabular}{|c|c|c|c|}
\hline 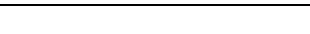 & Ekilecek Arazi & Alınacak Gelir & \multirow{6}{*}{$\begin{array}{l}\text { Yirmi y1l zarfinda her yilın ortalama } \\
\text { geliri } 590.625 \text { Osmanlı lirasıdır. }\end{array}$} \\
\hline 1 ila 5'inci seneye kadar & $\% 25$ & 236.250 & \\
\hline 5 ila 10'uncu seneye kadar & $\% 50$ & 472.500 & \\
\hline 10 ila 15 'inci seneye kadar & $\% 75$ & 708.750 & \\
\hline \multirow[t]{3}{*}{15 ila 20 'nci seneye kadar } & $\% 100$ & 945.000 & \\
\hline & & 2.362 .500 & \\
\hline & Genel Ortalama & & \multirow{4}{*}{ Toplam Osmanlı lirasıdır. } \\
\hline 20'nci seneye kadar & $\% 100$ & 590.625 & \\
\hline 35 'inci seneye kadar & $\% 100$ & 945.000 & \\
\hline 35 'inci seneden sonra & $\% 100$ & 1.172 .500 & \\
\hline
\end{tabular}

EK 2. Yeni Konulacak Vergi İle Elde Edilecek Toplam Gelir

\begin{tabular}{|l|l|l|l|l|l|}
\hline & Gayr-i Safi Gelir & & Net Gelirin Yüzde Onu & $\begin{array}{l}\text { Gelir } \\
\text { Osmanlı Liras1 }\end{array}$ \\
\hline 1 ila 20'nci seneye kadar & & & & $=$ \\
\hline 20 ila 35'inci seneye kadar & 590.625 & + & 258.963 & & 8.588 \\
\hline 35'inci seneden sonra & 945.000 & + & 413.943 & 1.358 .943 & $=$ \\
\hline
\end{tabular}

EK 3. 1913 Tarım İstatistiğinde Adana Vilayetinde Ziraatı Yapılan Ürünler

\begin{tabular}{|c|c|c|c|c|c|c|}
\hline Ürün Cinsi & $\begin{array}{l}\text { Ekilen Arazi } \\
\text { (Dönüm) }\end{array}$ & $\begin{array}{c}\text { Elde Edilen } \\
\text { Mahsül (Ton) }\end{array}$ & $\begin{array}{l}\text { Gelir (Bin } \\
\text { Gruş) }\end{array}$ & Ürün Cinsi & $\begin{array}{c}\text { Elde Edilen } \\
\text { Mahsül (Ton) }\end{array}$ & $\begin{array}{c}\text { Gelir (Bin } \\
\text { Gruş) }\end{array}$ \\
\hline Pamuk & 829.690 & 27.072 & 147.706 & Portakal & 7.263 & 2.831 \\
\hline Buğday & 682.118 & 135.530 & 110.037 & Erik & 287 & 40 \\
\hline Arpa & 452.305 & 54.277 & 30.553 & İncir & 273 & 81 \\
\hline Susam & 282.540 & 9.718 & 19.883 & Nar & 201 & 79 \\
\hline Yulaf & 161.618 & 20.568 & 11.099 & Limon & 155 & 36 \\
\hline Üzüm & 145.740 & 15.414 & 6.007 & Kay1S1 & 84 & 66 \\
\hline Dar1 & 22.204 & 3.419 & 1.823 & Elma & 79 & 9 \\
\hline Misir & 21.531 & 2.120 & 1.837 & Badem & 55 & 172 \\
\hline Soğan & 9.669 & 1.579 & 615 & Ceviz & 25 & 24 \\
\hline Fasulye & 8.223 & 1.072 & 1.107 & Amut & 4 & 3 \\
\hline Mercimek & 8.013 & 1.085 & 1.332 & Dut & 1 & 0 \\
\hline Nohut & 6.624 & 653 & 636 & TOPLAM & 8.427 & 3.341 \\
\hline Burçak & 4.414 & 408 & 212 & & & \\
\hline Tütün & 2.729 & 152 & 327 & & & \\
\hline Patates & 2.612 & 606 & 236 & & & \\
\hline Sarımsak & 1.047 & 84 & 98 & & & \\
\hline Çavdar & 1.000 & 33 & 16 & & & \\
\hline Pirinç & 900 & 143 & 234 & & & \\
\hline Bakla & 810 & 138 & 215 & & & \\
\hline Keten & 250 & 10 & 11 & & & \\
\hline Bezelye & 155 & 4 & 7 & & & \\
\hline Pancar & 120 & 22 & 4 & & & \\
\hline Kaplıca & 100 & 12 & 5 & & & \\
\hline Kuşyemi & 50 & 2 & 0 & & & \\
\hline Havuç & 35 & 9 & 3 & & & \\
\hline TOPLAM & 2.644 .497 & 274.130 & 334.003 & & & \\
\hline
\end{tabular}

Kaynak: Tevfik Güran (Haz.). (1997) Osmanlı Dönemi Tarım İstatistikleri 1909,1913 ve 1914. Cilt.3 T.C. Başbakanlık Devlet İstatistik Enstitüsü. Ankara, s.87-134 
Çukurova Üniversitesi Sosyal Bilimler Enstitüsü Dergisi, Cilt 30, Sayı 3, 2021, Sayfa 206-222

\section{EK 4. Süleyman Sırrı Bey’in Hazırladığı Çalışmanın Kapağı}

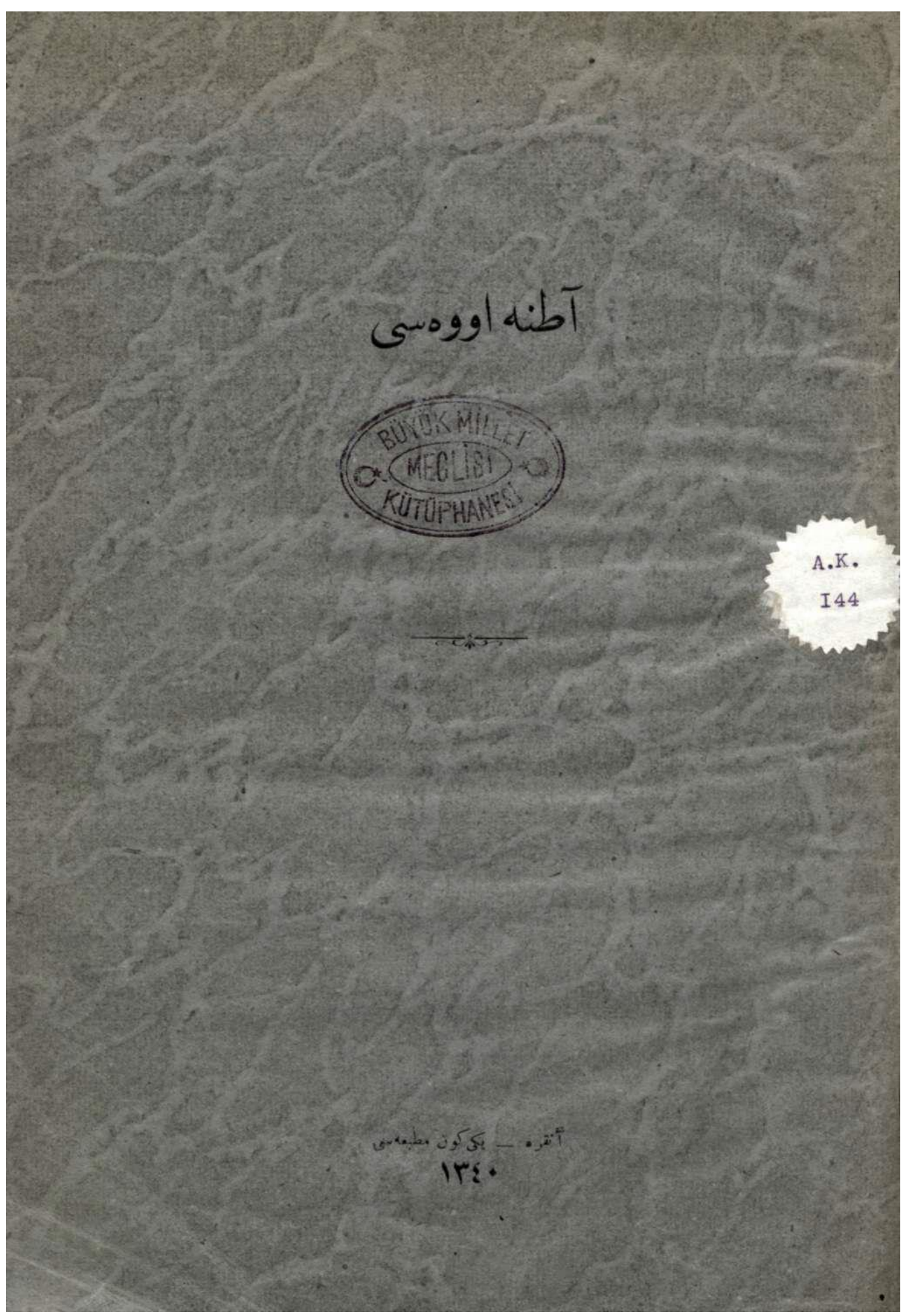


Çukurova Üniversitesi Sosyal Bilimler Enstitüsü Dergisi, Cilt 30, Sayı 3, 2021, Sayfa 206-222

EK 5. Adana Vilayetinin Sulama Projesi ve Nehirdeki Su Miktarını Gösterir Plan

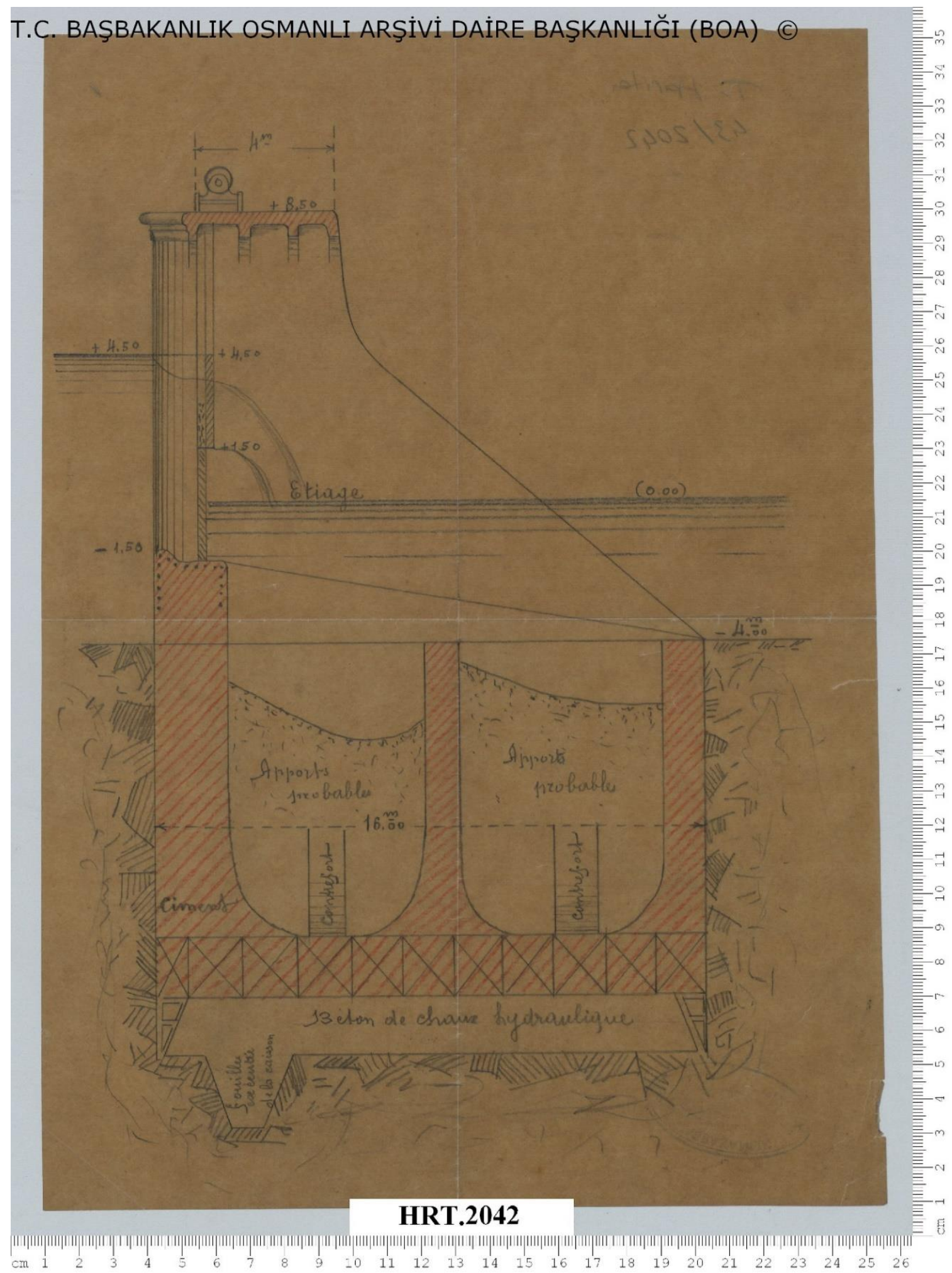


Çukurova Üniversitesi Sosyal Bilimler Enstitüsü Dergisi, Cilt 30, Sayı 3, 2021, Sayfa 206-222

\section{EK 6. Osmanlı Döneminde Hazırlanan Harita Örnekleri}
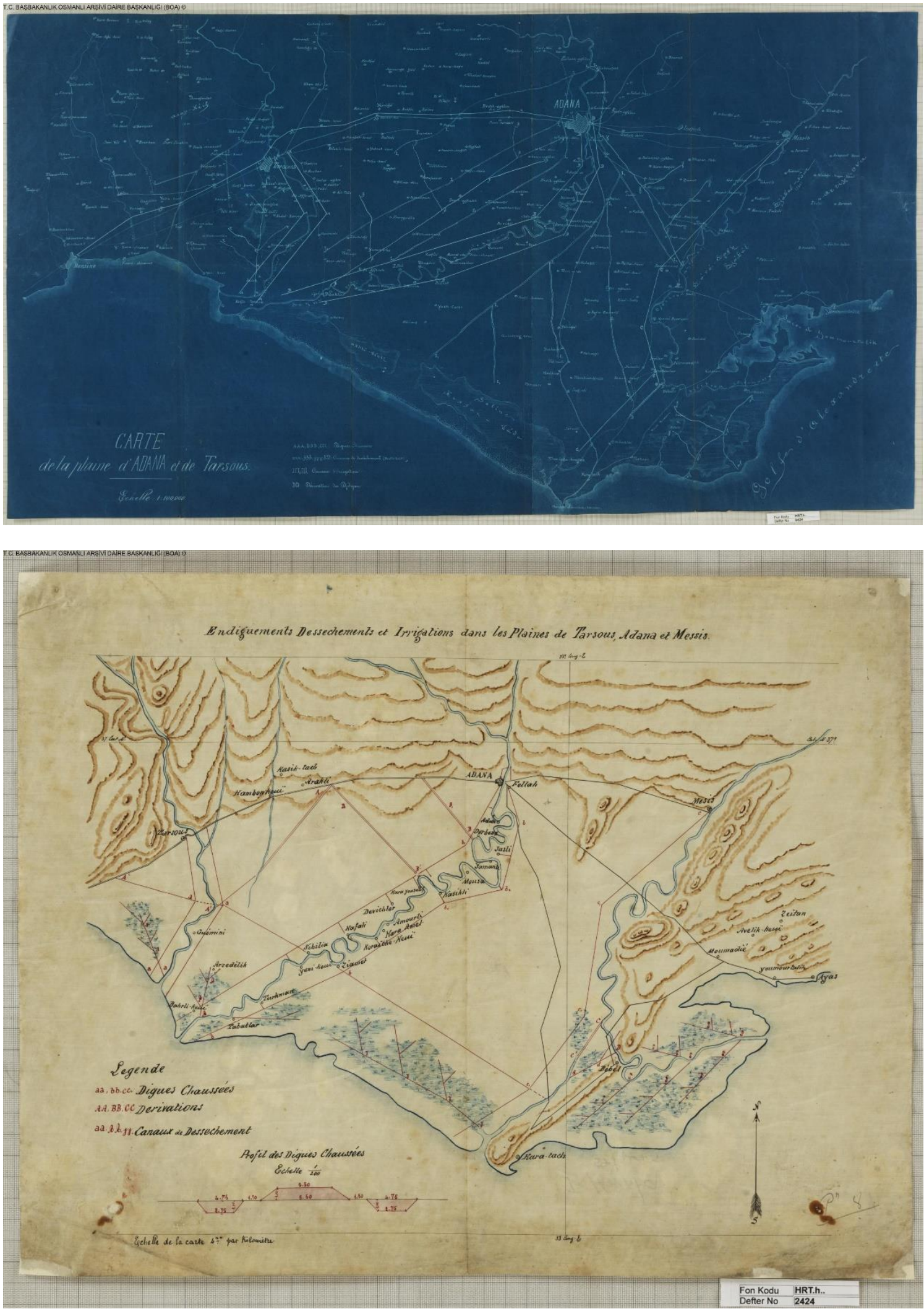
Çukurova Üniversitesi Sosyal Bilimler Enstitüsü Dergisi, Cilt 30, Sayı 3, 2021, Sayfa 206-222

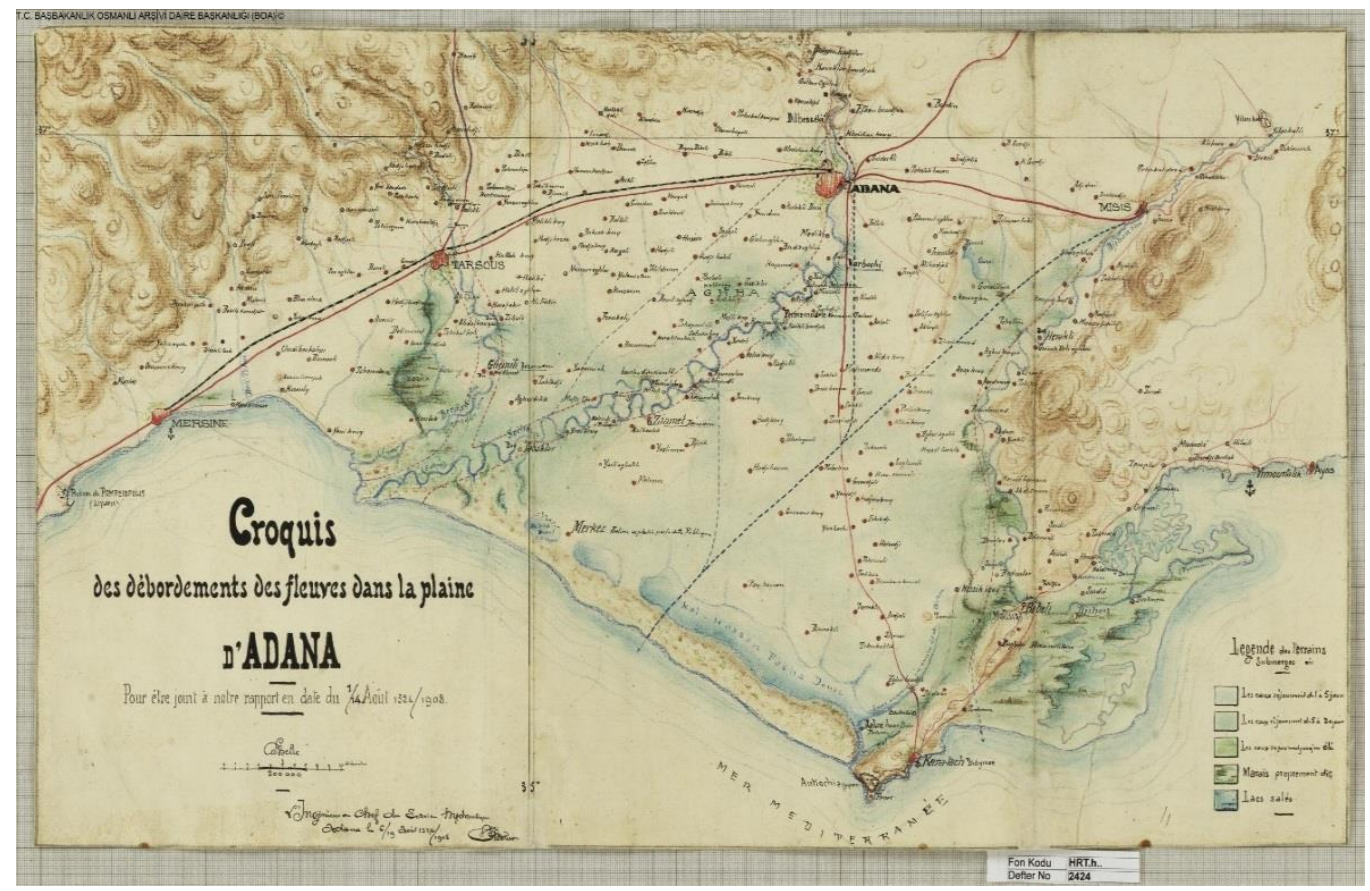

